\title{
SMPD1 Gene
}

National Cancer Institute

\section{Source}

National Cancer Institute. SMPD1 Gene. NCI Thesaurus. Code C105019.

This gene plays a role in ceramide metabolism. 